\title{
Adipose Tissue
}

National Cancer Institute

\section{Source}

National Cancer Institute. Adipose Tissue. NCI Thesaurus. Code C12472.

A specialized form of connective tissue consisting primarily of adipocytes (fat cells), surrounded by a meshwork of collagen fibers. 